\title{
Theory and social work: A conceptual review of the literature
}

DOI:

10.1111/ijsw. 12215

\section{Document Version}

Accepted author manuscript

Link to publication record in Manchester Research Explorer

\section{Citation for published version (APA):}

Hicks, S. (2016). Theory and social work: A conceptual review of the literature. International Journal of Social Welfare, 25(4), 399-414. https://doi.org/10.1111/ijsw.12215

\section{Published in:}

International Journal of Social Welfare

\section{Citing this paper}

Please note that where the full-text provided on Manchester Research Explorer is the Author Accepted Manuscript or Proof version this may differ from the final Published version. If citing, it is advised that you check and use the publisher's definitive version.

\section{General rights}

Copyright and moral rights for the publications made accessible in the Research Explorer are retained by the authors and/or other copyright owners and it is a condition of accessing publications that users recognise and abide by the legal requirements associated with these rights.

\section{Takedown policy}

If you believe that this document breaches copyright please refer to the University of Manchester's Takedown Procedures [http://man.ac.uk/04Y6Bo] or contact uml.scholarlycommunications@manchester.ac.uk providing relevant details, so we can investigate your claim.

\section{OPEN ACCESS}




\title{
Theory and social work: A conceptual review of the literature
}

\author{
Stephen Hicks
}

School of Health Sciences, University of Manchester, UK

Key words: social work theory, conceptual review, social work research, theory/practice divide, social work and philosophy, evidence-based practice

\begin{abstract}
This article presents a conceptual review of the literature concerning social work and theory. Based on analysis of 93 research studies, drawn from literature in English published between 1968 and 2016, the review considers the many ways that theory is conceptualised in the literature, and asks meta-theoretical questions about how and why different conceptualisations arise. The article examines definitional questions and ambiguities concerning the use of theory, extant research on the use of theory by social workers in practice, hostility expressed regarding theory in social work, the theory/practice divide, and perspectives that emphasise theory's utility or functionality. The article points at some methodological and ethical limitations concerning current research, and summarises dominant, as well as less prominent, versions of what counts as theory within the social work discipline, before finally suggesting that further meta-theoretical research is needed.
\end{abstract}

This is an author accepted version of a manuscript published in International Journal of Social Welfare (2016). Copyright John Wiley \& Sons Ltd. 
It would appear that social work has a problem with theory. That is, the contexts in which theory is discussed at all are usually those where it is some kind of problem to be resolved. Talk about theory in social work provokes accusations of impracticality, intellectual snobbery, ivory-tower privilege, or even coldness, and there are arguments that social work could do without it. For example, a report on UK social work education states that universities 'have been allowed to provide too much theory, too much sociology and not enough about spotting things in a family which are wrong' (Narey, 2014, p. 30). However, many make a case for theory's relevance and importance to social work, with Sibeon, for example, stating, '...'theoryless practice” is a contradiction in terms' (Sibeon, 1991b, p. 7). Nevertheless, as Pilalis (1986, p. 80) noted, terms 'such as "tension"..., "conflict"..., "lack of fit" or "gap"... and even "gaping hole" are used to account for what is usually described as the theory/practice divide.

Part of the problem, here, is what counts as theory, not what theory is appropriate or what theory is relevant. Within social work, various competing conceptualisations of theory exist, and so practitioners, academics, researchers, students and policy-makers may be talking about quite different notions, or from different ontological positions, when they talk about theory. Further, what counts as theory in social work is itself cast as a political question, since 'groups of people gain an interest in a particular theory and support it in arguments with groups of people who support other theories' (Payne, 2014, p. 20). The question of what gets counted as theory, then, becomes an important practical, moral and epistemological one, which has important consequences for social work.

Rather than a focus on the more familiar 'Is theory relevant to practice?' question, this article takes a step back in order to investigate how theory is variously conceptualised within social work. This is necessary because there is danger in assuming a shared understanding, and because there is very little meta-theory within the discipline. Here, feminist meta-theory 
(Christian, 1987; Stanley \& Wise, 2000) is an important inspiration, in that this asks what counts as theory, including questions about its form, how it is counted and whose work is seen to count. In social work, however, this 'theory of theory' (Poulter, 2005, p. 208) is lacking, and it is this meta-theoretical concern that forms the basis for this review: How is theory currently conceptualised and used in existing social work literature and what can be learned from this?

\section{Conceptual review}

Conceptual review, unlike the more usual, aggregative type of literature survey, involves examination of how the topic in question is theorised (Harkness, 1989; Palmer, 2011), in order to "reveal, "at a conceptual level," the frames of reference, theoretical debates, and interpretive arguments that [are] common to the wider body of literature' (Young et al. 2006, p. 325). For this reason, conceptual review includes both qualitative and quantitative studies, as well as non-empirical pieces, is less concerned with summarising, appraising and analysing findings, and instead focuses on methodological and epistemological processes by which a topic - theory - is produced.

In order to carry out this review, the date range 1968-2016 was used, with Timms (1968) taken as the starting point. This decision was taken because conceptual review considers patterns and changes in theorisation of a topic over time and, although a more recent start date would have decreased the volume of studies requiring consideration, this would also, inevitably, have focused only on contemporary ways of thinking. The electronic databases, Applied Social Sciences Index \& Abstracts, PsychINFO, Social Care Online, Social Services Abstracts and the Web of Science, were searched using keywords 'social AND work* AND theory'. However, other keywords, such as 'knowledge', 'science' and 'evidence', were also used in place of 'theory', as these often feature in existing studies 
concerned with the nature of social work knowledge or research methodology. Initial results produced about 1,900 relevant hits, based on a reading of abstracts and keywords.

In addition, a hand search was undertaken because computer database searches are not exhaustive (Aguirre \& Bolton 2014; Britten et al. 2002). Keyword searches of library catalogues were used to identify relevant books and book chapters, and reference lists or bibliographies were examined, in order to highlight pieces that had not already been picked up in the database or catalogue searches. This produced a further 96 results, mainly books and book chapters, and five reports or knowledge reviews published on the World Wide Web.

After excluding duplicates and those pieces that mentioned one of the search terms but were not substantively concerned with the nature of theory, evidence, knowledge or science within social work, 267 pieces were chosen for inclusion in the conceptual review, consisting of 171 journal articles, 72 books, 19 book chapters, three knowledge reviews and two reports on social work education and policy (see Table 1, Appendices). All 267 were analysed, but this figure was then reduced to 93 key studies for the purposes of the present article due to limitations of space. Studies were excluded if they focused solely on one model of practice or on one theorist, or on aspects of classroom teaching. Where one debate (e.g. on evidencebased practice) or the work of one author on a particular topic was present across a number of studies, then one or two representative articles were chosen. Introductory textbooks on theories for social work were also excluded, as they have been reviewed elsewhere (Payne, 2014). Table 1 summarises these exclusion/inclusion decisions. The studies included are drawn primarily from the United States, Canada, the United Kingdom, Ireland and Australia, as those countries dominate the literature in English, though there are also single studies from Israel, Sweden, Denmark, Hong Kong and China.

Lastly, a mapping exercise of concepts and approaches to questions of theory in the studies was carried out, and this was used to structure the review into five key areas: 
definitional ambiguity, findings from empirical studies, hostility, the theory/practice divide, and questions about function. This was an iterative process, one that involved assessing ways that the studies addressed theory, re-examining them to look for tropes or significant, recurring themes, and then deciding on just five key areas to address in detail, once again, due to limitations of space. Each study was then mapped against the five tropes. Table 2 (Appendices) summarises this mapping exercise, and shows that definitional ambiguity is by far the most common trope, with $93 \%$ of the chosen studies addressing this point. Theory utility or function is addressed by $76 \%$ and the theory/practice divide by $65 \%$ of the studies. Just $38 \%$ of the studies discuss hostility towards theory and only $18 \%$ are based on empirical investigation of theory and social work.

\section{Definitional questions and ambiguity}

Ninety-three per cent of the studies either define theory or raise the question of ambiguity concerning its meaning within social work. That many of the studies attempt to define theory is not surprising but, given that various ontological views concerning the nature of theory are adopted, these are not always made explicit. That is, definitions may be provided without reflexivity, so that the version of theory presented may appear factual rather than based on any kind of explicit epistemological, ethical or ontological stance. Further, any reader considering this range of perspectives will encounter definitional ambiguity, since existing social work literature displays many, sometimes incompatible, conceptualisations. However, it is important to note that this is not peculiar to social work. In the words of Mills $(2008$, p. 19), theory 'remains an elusive category with fuzzy boundaries that involve often hazy adjudications as to what is "theoretical enough".

There are some common themes to the various definitions; for example, theory is often described as a set of ideas, assumptions or a framework used to explain phenomena 
(Coady, 2008; Howe, 1987; Oko, 2011; Thompson, 2010; Thyer, 2001). However, this may suggest that theory is merely an explanatory device for already-given behaviours, persons or events, which tends to see interpretation merely as a functional task. That is, the notion that phenomena might be constructed via, or the result of, theory hardly features in such accounts. For others, theory ought to provide methods or justification for social work practice (Beckett \& Horner, 2016; Borden, 2010; Greene, 2009; Trevithick, 2012), sometimes combined with the explanatory role to provide a basis for action (Fook, Ryan \& Hawkins, 1997; Healy, 2014; Shaw \& Norton, 2007). Payne's argument that theory is a 'social construction' (Payne, 2014, p. 17) acknowledges that definitions of social work theory are disputed, may change over time and, crucially, that what counts as theory is a meta-theoretical question, since this involves powerful assertion and reproduction of ideas.

Less common is the view of theory as a form of praxis (Evans, 1976; Ferguson, 2009; O’Brien, 2004; Penna, 2004; Pozzuto, 2007; Rojek, Peacock \& Collins, 1988), a perspective that has emerged at particular times, usually associated with what is described as radical, structural or critical social work. Here, three key moments emerge as especially significant: first, the rise in the 1970s of the radical social work movement which argued for analysis of ideology within social work and for a practice that challenges oppressive relations (Bailey \& Brake, 1975; Brake \& Bailey, 1980; Statham, 1977); second, a re-emergence in the 1990s (Langan \& Lee, 1989; Mullaly, 1993), alongside, but in part a challenge to, the development of anti-discriminatory practice (Thompson, 1992); and third, recent accounts (Ferguson \& Woodward, 2009; Hick, Fook \& Pozzuto, 2005; Lavalette, 2011; Turbett, 2014), which have argued for the need to reinvigorate social work with critical and social structural perspectives.

Perhaps the most striking source of conceptual disagreement in the literature associated with the definition of theory in social work, however, has to do with epistemological and ontological differences, or "philosophical debates about knowledge, the 
nature of reality, and how we know and represent that reality' (Mäntysaari \& Weatherley, 2010, p. 180). This takes place between those who take up positivist versus interpretivist epistemological positions. In the former, theory is about hypothesising or prediction (Teater, 2014), and has taken a number of forms at various times. First, there have been arguments, especially in the USA that social work ought to be scientifically based, and that theory should be a logical explanation for empirically verified facts (Thyer, 2008; Turner, 1974). Second, authors, such as Sheldon, have argued for an 'injection of positivism' into social work (Sheldon, 1978, p. 18). Third, those who propose evidence-based practice have also suggested that theory ought to be potentially refutable, reliable and valid (Gambrill, 2012; Rubin, 2015; Sheldon \& Macdonald, 2009).

This is opposed by authors who argue for interpretivist accounts of social work knowledge, based on social, rather than natural, sciences (Heineman, 1991; Nevo \& SlonimNevo, 2011; Paley, 1987; Penna, 2004; Peile, 1994; Taylor \& White, 2000; Witkin, 2011, 2016). Thus, in response to Thyer's (2001) argument that social work research ought to be based upon experimental, outcome studies that are 'essentially theory-free' (Thyer, 2001, p. 18), Gomory (2001) responds that assumptions about objective data are naïve, since theories about what to look for in research precede any kind of data generation. Here, interpretivist accounts focus on knowledge, not as product applied in an 'instrumental' fashion (Webb, 2001, p. 73), but rather a concern with how it is made via interactional and contingent processes. Social work is seen as a value-based and human practice that does not adhere to many of the requirements of evidence-based approaches. Further, as noted by Smith (1987, p. 412), '[f]acts do not speak for themselves' (Smith,), since the role of theory as a form of interpretation is key. Indeed, England (1986) argues for an arts-based analysis because this allows for the complexity, subjectivity and ephemerality of social work practice. However, insights gained via artistic criticism are no less disputed than those of science, and so no 
'more capable than positivist scientific rigour of providing a stable foundation for investigating social work' (Smith, 1987, p. 412).

Existing studies highlight different versions of theory used within social work, with earlier studies referring to theories about social work's purpose, as models for practice, or as being derived from the social sciences (Timms \& Timms, 1977). The latter two notions relate to Curnock and Hardiker's 'practice theory' (theory that comes from, or is developed in, practice) and 'theories of practice' (theories from outside social work, applied to practice) (1979, p. 10), a formulation developed as part of a UK-based research project that analysed 90 social inquiry/assessment reports, as well as structured interviews with social workers and probation officers. Their respondents drew on theories of practice in their assessments, but, in none of the cases did they 'strictly adhere to one or more theoretical stance because they had to rely on other knowledge besides their explicit theories' (Curnock \& Hardiker, 1979, p. 98).

Curnock and Hardiker's research has thus identified a split between theories outside of practice, or what Oko (2011) refers to as capital-T, textbook-type theories, and theories from within practice, or informal ones. Here, it becomes important to remember that this either/or description refers not to how things are but rather to a conceptualisation that begins, at the same time, to be referred to as the theory/practice divide, a notion given specific attention later in this article. It is also relevant to note the normative nature of this position, with the suggestion that any theory not directly from or for practice may be treated with suspicion.

\section{Findings from empirical studies}

Just $18 \%$ of the studies reviewed are based on empirical research and, while this might surprise some readers, it also indicates that most of the work on theory and social work is either speculative or applied. The empirical studies demonstrate both that there are different kinds of theorising going on within social work, but also that some are more likely to be 
recognised as theory than others. Some studies tend to investigate the use of capital-T-type, propositional theory and the appliance of objective or existing knowledge. Others are concerned with how understandings of theory depend on contextual and temporal changes, and with making sense of practice from within. This alternative view is a 'generative' one (Pozzuto, 2007, p. 69) in which to theorise is to produce rather than apply understanding. Exemplifying the former approach, Marsh and Triseliotis' British study, based on questionnaires from 714 social workers/probation officers and 69 supervisors, plus interviews with 60 newly-qualified staff and 31 supervisors, suggests that newly qualified staff are far more likely than seniors to see theory as relevant. However, while $81 \%$ of respondents said that they applied theory, newly qualified staff said it was rarely discussed in supervision (Marsh \& Triseliotis, 1996, p. 160). Marsh and Triseliotis quantify the presence of theories within respondents' accounts, noting that counselling and task-centred theory were discussed by 15 and 14\%, while feminist and radical perspectives by just 4 and $2 \%$, respectively (Marsh \& Triseliotis, 1996, p. 51). This propositional theory approach is echoed in the study by Mackey, Burek and Charkoudian (1987, p. 371), based on questionnaire responses from 458 senior clinical social workers across the United States. Fifty-one per cent of the respondents stated that 'psychoanalytic ego psychology' was their primary theoretical orientation, with a further $19 \%$ stating family systems theory, $11 \%$ behavioural and cognitive therapies, and $8 \%$ sociocultural theories.

However, other studies have investigated theorising in practice and, relatedly, how both social work students and practitioners make sense of theory, not coincidentally based on qualitative and ethnographic research methods. Secker's British study, based on 21 interviews and 19 questionnaires with social work students, argues that, in the early stages, students rely on personal knowledge and beliefs, but treat information in a rather unquestioning way. Towards the middle of their studies, students use theory in a 'fragmented' way, treating 
theories as rulebooks, and assessing them as either right or wrong. Later, students develop a 'fluent' approach, where they see theories as building blocks that do not have to be applied rigidly (Secker, 1993).

These findings are echoed in the study by Fook, Ryan and Hawkins, based on interviews with 30 Australian social work students, as well as vignette-based discussions with 76 social workers and students. The newer students made sense of social work via personal views or those drawn from 'popular psychology', with little reference to theory (Fook et al., 2000, p. 33). By the end of their studies, although little formal theory was used, the students mentioned perspectives such as systems theory. Fook et al. (2000) found that newly qualified professionals speak of theory more often, but, like experienced practitioners, tend to use particular concepts, such as empowerment, child development or attachment, rather than whole theories. Similarly, in an ethnographic study by Avby, Nilsen and Ellström (2015, p. 8) based on observations, interviews and case record analysis with seven Swedish social workers, the respondents 'preferred practice-based knowledge and rarely consulted knowledge from sources found outside the practice setting'.

Lastly, there are studies that examine how the word theory is used or how practitioners make sense of their own use of theory in practice. Barbour's longitudinal study, based on participant observation and semi-structured interviews with 20 UK-based social work students, suggests that students use the term to refer to 'grand theory' such as Marxist or Freudian perspectives, to 'mid-range' theory that offers an explanatory framework, and to anything 'covered in class and thus learnt at university' (Barbour, 1984, p. 558). Further, some students view 'theoretical abstractions ... with suspicion as they [abstractions] obscured the true nature of the social work task as an essentially practical one' (Barbour, 1984, p. 561). Practice supervisors did not always encourage students to see theory as useful, and 'this anti- 
theoretical orientation was extolled by students as evidence of the quality of the social worker in question' (Barbour, 1984, p. 561).

Some studies suggest that theory is used without reflexivity or acknowledgement, in an entirely personal way, and therefore that explicit acknowledgement of theory is not a preferred cultural practice. For example, in Barbour's study, some students described theory as something which “"seeped in” and was used unconsciously,' (Barbour, 1984, p. 566). Carew's study, based on recordings of 20 English social workers' activities, as well as their responses to a questionnaire, also suggests that theory's utilisation is 'unconscious' (Carew, 1979, p. 353). Arnd-Caddigan and Pozzuto's institutional ethnography, based on American child welfare workers' written responses to a simulated client situation, and on unstructured interviews, similarly suggests that, even where a social worker does 'not believe she was using formal theory, she may have in fact done so' (Arnd-Caddigan \& Pozzuto, 2008, p. 61).

\section{Hostility towards theory}

The question of whether the social work discipline displays hostility towards theory is discussed in several studies, $38 \%$ of all those considered. Hostility arises either via antiintellectualism or the downplaying of theory's potentially unsettling role by those who take an instrumental, skills or outcome-focused view of knowledge, something which several authors argue has increased under neoliberal, governmental regimes. That is, in some cases, such as that reported by Narey (2014), social work is regarded as an essentially practical, ameliorative activity which does not need theory and in which theory is seen as impractical or inappropriately political. Thus, hostility may be directed towards theory as such or towards its perceived lack of utility, with some arguments taking up an instrumental view of knowledge for social work. 
In the quote below, Cohen discusses the relationship between sociological theory and social work, and suggests that practitioners':

... most familiar reaction ... is ... that, however interesting, amusing, correct and even morally uplifting our message might be, it is ultimately a self-indulgent intellectual exercise, a luxury which cannot be afforded by anyone tied down by the day-to-day demands of a social-work job (Cohen, 1975, p. 76).

Cohen notes that such hostility takes either an extreme form ('it's all right for you to talk, we're the ones doing the dirty work') or a less defensive position, which, while interested in the sociologist's claims, remains baffled about their application. However, he argues that hostility may arise because theories such as radical social work are 'extremely evasive' on questions of application to practice (Cohen, 1975, p. 86), and he suggests that dismissals of social workers' perspectives are not only patronising, but do little to address genuine questions about how to put theory into practice.

Others have argued that anti-intellectualism is present in social work, but that this has been encouraged by the increasing state regulation of social work education, including prioritisation of employer-led syllabi and a general hostility towards the social sciences (Green, 2006). Jones argues that, in the UK, social work education is 'unique in its antiintellectualism and its hostile stance to the social sciences' (Jones, 1996, p. 190), echoed by England, who goes so far as to say, 'social workers have not developed any adequate tradition of intellectual scrutiny and criticism, and their thinking - in the job and in writing - is often lazy' (England, 1986, p. 6). Singh and Cowden note that the intellectual is not often linked with social work, but state that this is due to an association of the word with "the "ivory tower" and detachment from the everyday' (Singh \& Cowden, 2009, p. 480). Instead, they 
argue for a wider notion of the intellectual to include practical activities, which embed theory within everyday practice.

Some authors, such as Howe $(1987,1996)$ and Houston $(2001,2014)$, have argued that the dangers in anti-intellectual and instrumental views of theory are that these see knowledge as merely practical or skills-based and that this results in shallow or surface accounts of, or engagement with, the kinds of complex human situations that social workers face. Howe suggests that theory is sometimes seen as pretentious and effete, opposed to 'practical ... down-to-earth wisdom' (Howe, 1987, p. 1), but argues that all practice is theoretical and that the 'choice of a theory for practice is also a choice about the kind of activity social work is taken to be' (Howe, 1987, p. 166). He cautions that the discipline is becoming 'analytically more shallow and increasingly performance-orientated' (Howe, 1996, p. 77), and suggests that neo-liberal welfare favours a performance culture of targets and outcomes, in which theory is rejected in favour of 'task-focused and contract-orientated practices' (Howe, 1996, p. 90).

Houston has taken up these points, cautioning against 'overly instrumentalised responses governed by procedures, competencies and managerialism' (Houston, 2001, p. 853), and advocates moving from 'surface appraisal (of facts and feelings) to one of depth ... attuned to "deep causality",' a project that defends 'philosophy in a run away world that privileges instrumentalism in social life' (Houston, 2014, pp. 59-60). While it is important, here, to note that some perspectives raise questions about the deep causes suggested by critical realism, these arguments suggest that hostility towards theory is part of a wider move in the direction of short-term, surface welfare regimes under neoliberal forms of government. 


\section{The theory/practice divide}

The theory/practice divide is a prevalent concept in the literature, present in $65 \%$ of the studies, indicating that, for some, these are seen as separate, even incompatible, worlds. Here, however, there is a danger of assuming a divide, and that this divide, rather than the assumption, is the problem to be investigated. This assumption limits some of the studies by taking the divide as read, rather than asking how the notion of divide arises, and is perpetuated in various ways. In relation to the conceptualisation of theory, proponents of the divide tend to work with the propositional, theories of practice model, one which tends not to recognise generative or interpretive accounts or practitioners' thinking and grounded practices as theorising. Coulshed and Orme suggest the 'continuing tension between practice and theory' depends on this confusion between theories for practice (social science-type), of practice (how to do social work-type) and from practice (implicit, practice wisdom-type) (Coulshed \& Orme, 2012, pp. 1-10).

There are also analyses that attempt to account for the divide. Curnock and Hardiker (1979) argue that much practice wisdom does not get counted as theory because so little of it is written down, a point also made by others, who refer to social work's word-of-mouth culture (England, 1986; Fook, 2012; Oko, 2011; Sibeon, 1991b). Sibeon (1991a) adds that social work practice not only prioritises oral over written expression of methods, but favours individual experience. For example, partnership working, anti-discriminatory theory, or research based on capturing participants' experiences may treat service users' accounts as authentic and unquestionable, to be prioritised over others. This is a crucial point because, where theory is dismissed as irrelevant, there is, at the same time, ignorance of the ways in which practice wisdom operates its own epistemological assumptions, such as those that favour individual experience as a basis for knowledge. 
Others suggest that the divide arises because academic and research-based accounts of social work come from different institutional spaces than those of practitioners and service users (Heinsch, Gray \& Sharland, 2015; Smid \& van Krieken, 1984; Trevithick, 2012). Fook (2002) argues such disparities are increasing, but, given the emphasis on involvement of service and other research users in contemporary studies, including the rise of some practitioner and service user-led research, this may be changing. Fook (2012) also suggests that academic and research-based authority is now no longer taken-for-granted. Instead, she refers to bottom-up, inductive and top-down, deductive theories, both of which are needed for social work, and describes these as different 'ways of knowing', in order to avoid the suggestion that researchers and academics theorise, while practitioners use everyday wisdom. Carew's study argues that the theory/practice divide may be exaggerated:

Only two of the participants thought that the part played by theory in practice was relatively unimportant. The rest of the participants considered it to be important, maintaining that it acts as a framework from which to practise (Carew, 1979, p. 353).

However, few of the social workers in Carew's study referred to formal theory; they talked instead about practice wisdom. In part, this was because they lacked access to research, and sought wisdom about ways to practice from colleagues. For Carew, however, the propositional knowledge view of theory promotes the theory/practice divide, since it undermines an ability to understand what knowledge social workers already use as a form of theorising.

\section{Theory as functional}

For Smeeton, theory is best imagined a 'region of thought' rather than a tool, since when social workers 'adopt theories as tools, they tend to become sledgehammers' (Smeeton, 2015, 
p. 6). However, within social work, theory is often disparaged for its lack of function, value to practice or applicability (Sharland, 2012, 2013). That is, it is seen as a mere tool, although those who point out that theory promotes critical thinking, or that it has a legitimate role other than utility, do not accept this. Timms, for example, states that " practice" is distorted if it is conceived as simply a matter of applying "theory" or even of applying "theories," and "theory" is misread if it is seen as some kind of summary of "practice"” (Timms, 1968, p. 23). Both Garrett and Thompson raise concerns about the one-way view of theory as something merely to be applied (Garrett, 2013; Thompson, 2010), and Kreisberg and Marsh argue that 'much utilisation of research occurs on a conceptual level, as compared with an instrumental, means-ends level' (Kreisberg \& Marsh, 2015, p. 15 of 20).

The emphasis on theory's functionality, or 'knowledge as product' (Sheppard, 1998, p. 765), relates to what Kondrat (1995, p. 410) terms a 'technical framework', in which knowledge is something to be applied or used. Ayre and Barrett caution that the relationship between theory and practice is more complicated than theory as 'a solid substrate or a set of well-laid foundations on which the edifice of hands-on intervention can be constructed' (Ayre \& Barrett, 2003, p. 125). Indeed, they note that contingent matters, such as practical resources, affect whether theoretical perspectives are taken up, a point echoed by others (Chan \& Chan, 2004).

Here, political aspects of theory enter the picture in a number of senses. First, theory is concerned with praxis, linked to social work's role in challenging oppression (Leonard, 1975; Witkin \& Gottschalk, 1988). Second, the processes by which realms of thought become designated theory or not, and whether they make it into textbooks or a canon, are political or material, not just ideas in the head. Third, that there is, relatedly, a hierarchy of theories. Ayre and Barrett argue that certain theories 'become dominant because they work particularly well for social groups who have the power to make them dominant, and not because they are more 
"right" or more "accurate" in any absolute sense' (Ayre \& Barrett, 2003, p. 131). In this sense, it is not so much that practice is underpinned by theory, but rather that theory is underpinned by what practices, including the operations of power, allow. It is for this reason that Ferguson resists a 'closed system' of theory, in order to critique neo-liberal versions of what counts as appropriate social work knowledge (Ferguson, 2009, p. 214), also crucial for the opening up of new, rather than designated, ways of thinking.

This relates to the processes by which less privileged perspectives, particularly those associated with race or gender, for example, are either written out of the canon of theory or merely added in to its peripheries. Graham argues that ethnocentric processes result in black perspectives being merely 'articulated as an adaptation or modification of existing theoretical frameworks' (Graham, 1999, p. 254), and, in Wachholz and Mullaly's (2001) content analysis of 14 introductory, American social work textbooks published between 1988-97, there is little coverage of radical, feminist or anti-racist scholarship.

On the question of gender and theory, some suggest that the professionalization of social work has prioritised the technical-rational view, side-lining practice wisdom produced mainly by women. As a result, technical-rational views have gained greater prominence, particularly in the United States, and theory proper has become associated with the men that dominate senior academic posts. However, Weick argues for re-valuing practice wisdom, and holding academic theory to account:

The profession's first voice is found most fully in what we have come to call practice wisdom, the accumulation of knowledge that is flavored with the richness and intricacies of years of collective practice experience ... That is not to say that academic theory should be jettisoned. However, it does mean that we must evaluate that theory according to the standards of both values and utility (Weick, 2000, pp. 400-401). 
However, while Weick asks what values a particular theory is based on, since technicalrational views usually jettison values in favour of objectivity, she also makes a case for theory's 'utility' (Weick, 2000, p. 401). This presents an interesting contradiction, since questioning the dominance of evidence-based, objective views does not necessarily sit well with a utilitarian account. Further, Weick's suggestion that theory has been promoted as part of a masculinist culture contradicts Howe's point that theory may be seen as effete (Howe, 1987). So, while Weick's point about epistemological positions, drawing on feminist critiques of mainstream ways of theorising, is important, it is also necessary to remember that gender does not necessarily map onto forms of knowledge in a straightforward, binary way.

\section{A meta-theory for social work?}

Before discussing the main approaches to theory and social work that have arisen from this conceptual review, it is vital to ask some methodological questions concerning extant literature. The studies based on interviews and questionnaires may be limited because they focus on what respondents say about theory, rather than observing how social workers theorise. That is, they may tell us little about interaction and the production of theory within practice settings. While narrative does tell us much about how people engage, too much reliance on extracts from interview data does not allow us to consider indexical production, the kinds of interactions within which theory emerges, or forms other than talk, such as visual data, which involve theory.

In the questionnaire or interview-based studies, reports about whether social workers think theory relevant are, first, a particular conceptualisation of what counts as theory and, second, do not take account of how they construct accounts of practice. The possibility that newly qualified staff might wish to present more competent accounts of theory, or that 
experienced practitioners might take up anti-theory perspectives, for example, does not feature in these studies. It is for these reasons, amongst others, that some researchers promote the use of ethnographic, observational methods, in order to ask how social workers theorise in practical contexts (Floersch, 2004; Sung-Chan \& Yuen-Tsang, 2008).

In addition to these methodological concerns, this review has demonstrated that ontological and epistemological assumptions concerning theory are vital. What counts as theory matters, in the sense that various authors conceptualise it in different ways, but also that there are political and material processes by which both abstract and practical thought get labelled as theory or not. That the studies reviewed in this article demonstrate definitional and philosophical ambiguity, or tensions concerning theory's nature, indicates differences between formal, propositional versus generative, in practice views of theory. However, this also indicates a more general ambiguity within theory, in the sense that to theorise involves philosophical questions that do not have agreed or straightforward answers. As Shaw and Norton (2007, p. 3) note, 'incommensurable philosophical presuppositions' mean that no 'coherent single framework' for social work knowledge is possible, a point that allows for expansion of the realm of theory and guards against the dominance of a narrowly defined range.

This review demonstrates that a formal, textbook-type view of theory dominates social work, influenced by positivist epistemologies which characterise arguments for evidencebased practice and suggest that theory takes the form of either hypothesis-testing or a methods-application model. Theory, from this view, is to have a use and is to be applied, and, where not derived from empirical studies, is often taken from outside of social work, for example, the social sciences. Two further, associated notions of theory are less dominant. The first is that social work derives theory from practice wisdom, often passed on via word-ofmouth. The second is that social work involves sense making, and theorises in practice. These 
are generative models, suggesting that social work formulates theory, rather than borrowing it from elsewhere or merely applying it.

This either/or approach to theory, however, does not take into account epistemological hierarchies or material processes of theory generation and confirmation. For example, because the formal, textbook view of theory dominates, then much of the theorising that goes on in practice is either disregarded or is not considered theory. A rather narrow, utilitarian view of theory also dominates, in which application or value is prioritised, and in which theory is required to specify methods, downplaying theory's role in challenging tacit knowledge or engaging critical thinking. This utilitarian view, however, is unhelpful because it tends to see theory as merely functional, something 'to "make sense" of things in order to help things work, without challenging what making sense might mean, who outcomes work for, etc.' (Grimwood, 2016, p. 6).

I have argued for meta-theory in social work, since recognition that differing conceptualisations of theory exist within social work is important, or, rather, greater reflexivity in writings about theory is needed. That there is relatively little empirical investigation of how theory is conceptualised and used within social work also indicates the need for further research but, as we have seen, this raises methodological as well as ontological and epistemological questions. I have also suggested that the narrow, textbook notion of theory is unhelpful, since this misses the processes of theorising, whether those be within social work practice scenarios, or the processes by which some forms of knowledge and some thinkers get to be called theory and theorists, while others do not. My point here is that the question, 'Do social workers use theory?' rests on a particular view of what counts as theory, and so does not pay attention to how they are already theorising. Social work phenomena are constructed through theorising, or, to put this differently, social work cases do not exist independently of their theorisation. This, of course, is a controversial point, but also 
reminds us that the differing ways the social work discipline conceptualises theory need further investigation.

\section{References}

Aguirre, R. T. P. \& Bolton, K. W. (2014). Qualitative interpretive meta-synthesis in social work research: Uncharted territory. Journal of Social Work, 14(3), 279-294. doi: $10.1177 / 1468017313476797$

Arnd-Caddigan, M. \& Pozzuto, R. (2008). Types of knowledge, forms of practice. The Qualitative Report, 13(1), 61-77.

Avby, G., Nilsen, P., \& Ellström, P. (2015). Knowledge use and learning in everyday social work practice: a study in child investigation work. Child and Family Social Work. Advance online publication. doi:10.1111/cfs.12227

Ayre, P. \& Barrett, D. (2003). Theory and practice: The chicken and the egg. European Journal of Social Work, 6(2), 125-132. doi: 10.1080/1369145032000144395

Bailey, R. \& Brake, M. (Eds.) (1975). Radical social work. London, UK: Edward Arnold.

Barbour, R.S. (1984). Social work education: Tackling the theory-practice dilemma. British Journal of Social Work, 14(6), 557-577.

Beckett, C. \& Horner, N. (2016). Essential theory for social work practice (2nd ed.). London, UK: Sage.

Borden, W. (2010). Introduction. In W. Borden (Ed.), Reshaping theory in contemporary social work: Toward a critical pluralism in clinical practice (pp. xi-xviii). New York: Columbia University Press.

Brake, M. \& Bailey, R. (Eds.) (1980). Radical social work and practice. London, UK: Edward Arnold.

Britten, N., Campbell, R., Pope, C., Donovan, J., Morgan, M., \& Pill, R. (2002). Using meta ethnography to synthesise qualitative research: A worked example. Journal of Health Services Research and Policy, 7(4), 209-215. doi: 10.1258/135591902320432732

Carew, R. (1979). The place of knowledge in social work activity. British Journal of Social Work, 9(3), 349-364.

Chan, K.L. \& Chan, C.L.W. (2004). Social workers' conceptions of the relationship between theory and practice in an organizational context. International Social Work, 47(4), 543557. doi:10.1177/0020872804046260

Christian, B. (1987). The race for theory. Cultural Critique, 6(Spring), 51-63. 
Coady, N. (2008). The science and art of direct practice: An overview of theory and an intuitive-inductive approach to practice. In N. Coady \& P. Lehmann (Eds.), Theoretical perspectives for direct social work practice: A generalist-eclectic approach (pp. 41-66). New York: Springer.

Cohen, S. (1975). It's all right for you to talk: Political and sociological manifestos for social work action. In R. Bailey \& M. Brake (Eds.), Radical social work (pp. 76-95). London, UK: Edward Arnold.

Coulshed, V. \& Orme, J. (2012). Social work practice (5th ed.). Basingstoke, UK: Palgrave Macmillan.

Curnock, K. \& Hardiker, P. (1979). Towards practice theory: Skills and methods in social assessments. London, UK: Routledge \& Kegan Paul.

England, H. (1986). Social work as art: Making sense for good practice. London, UK: Allen \& Unwin.

Evans, R. (1976). Some implications of an integrated model of social work for theory and practice. British Journal of Social Work, 6(2), 177-200.

Ferguson, I. (2009). Where's the beef? A response to Gray and Webb's 'The return of the political in social work'. International Journal of Social Welfare, 18(2), 213-217. doi:10.1111/j.1468-2397.2009.00648.x

Ferguson, I. \& Woodward, R. (2009). Radical social work in practice: Making a difference. Bristol, UK: Policy Press.

Floersch, J. (2004). A method for investigating practitioner use of theory in practice. Qualitative Social Work, 3(2), 161-177. doi:10.1177/1473325004043391

Fook, J. (2002). Theorizing from practice: Towards an inclusive approach for social work research. Qualitative Social Work, 1(1), 79-95. doi:10.1177/147332500200100106

Fook, J. (2012). Social work: A critical approach to practice $\left(2^{\text {nd }}\right.$ ed.). London, UK: Sage.

Fook, J., Ryan, M., \& Hawkins, L. (1997). Towards a theory of social work expertise. British Journal of Social Work, 27(3), 399-417. doi:10.1093/oxfordjournals.bjsw.a011220

Fook, J., Ryan, M., \& Hawkins, L. (2000). Professional expertise: Practice, theory and education for working in uncertainty. London, UK: Whiting \& Birch.

Gambrill, E. (2012). Uses of history in creating new futures: A science-informed social work. Research on Social Work Practice, 22(5), 491-491. doi:10.1177/1049731512443714

Garrett, P. M. (2013). Social work and social theory: Making connections. Bristol, UK: Policy Press.

Gomory, T. (2001). A fallibilistic response to Thyer's theory of theory-free empirical research 
in social work practice. Journal of Social Work Education, 37(1), 26-50.

doi:10.1080/10437797.2001.10779035

Graham, M. J. (1999). The African-centred worldview: Developing a paradigm for social work. British Journal of Social Work, 29(2), 251-267.

doi:10.1093/oxfordjournals.bjsw.a011445

Green, L. C. (2006). Pariah profession, debased discipline? An analysis of social work's low academic status and the possibilities for change. Social Work Education, 25(3), 245-264. doi:10.1080/02615470600565152

Greene, R. R. (2009). Human behavior theory, person-in-environment, and social work method. In R.R. Greene (Ed.), Human behavior theory and social work practice (pp. 126). New Brunswick: Aldine Transaction.

Grimwood, T. (2016). Key debates in social work and philosophy. London, UK: Routledge.

Harkness, D. (1989). Research and social work supervision: A conceptual review. Social Work, 34(2), 115-118.

Healy, K. (2014). Social work theories in context: Creating frameworks for practice (2nd ed.). Basingstoke, UK: Palgrave Macmillan.

Heineman, M. B. (1991). The obsolete scientific imperative in social work research. Social Service Review, 55(3), 371-397.

Heinsch, M., Gray, M., \& Sharland, E. (2016). Re-conceptualising the link between research and practice in social work: A literature review on knowledge utilisation. International Journal of Social Welfare, 25(1), 98-104.

Hick, S., Fook, J., \& Pozzuto, R. (Eds.) (2005). Social work: A critical turn. Toronto: Thompson Educational Publishing.

Houston, S. (2001). Beyond social constructionism: Critical realism and social work. British Journal of Social Work, 31(6), 845-861. doi:10.1093/bjsw/31.6.845

Houston, S. (2014). Meta-theoretical paradigms underpinning risk in child welfare: Towards a position of methodological pragmatism. Children and Youth Services Review, 47(1), 5560. doi:10.1016/j.childyouth.2013.12.003

Howe, D. (1987). An introduction to social work theory. Aldershot, UK: Wildwood House Ltd.

Howe, D. (1996). Surface and depth in social-work practice. In N. Parton (Ed.), Social theory, social change and social work (pp. 77-97). London, UK: Routledge. 
Jones, C. (1996). Anti-intellectualism and the peculiarities of British social work education. In N. Parton (Ed.), Social theory, social change and social work (pp. 190-210). London, UK: Routledge.

Kondrat, M. E. (1995). Concept, act, and interest in professional practice: Implications of an empowerment perspective. Social Service Review, 69(3), 405-428.

Kreisberg, N. \& Marsh, J.C. (2015). Social work knowledge production and utilisation: An international comparison. British Journal of Social Work. Advance online publication. doi:10.1093/bjsw/bcu147

Langan, M. \& Lee, P. (Eds.) (1989). Radical social work today. London, UK: Unwin Hyman.

Lavalette, M. (Ed.) (2011). Radical social work today: Social work at the crossroads. Bristol, UK: Policy Press.

Leonard, P. (1975). Explanation and education in social work. British Journal of Social Work, $5(3), 325-333$.

Mackey, R.A., Burek, M., \& Charkoudian, S. (1987). The relationship of theory to clinical practice. Clinical Social Work Journal, 15(4), 368-383.

Mäntysaari, M. \& Weatherley, R. (2010). Theory and theorizing: Intellectual contexts of social work research. In I. Shaw, K. Briar-Lawson, J. Orme, and R. Ruckdeschel (Eds.), The Sage handbook of social work research (pp. 180-194). London, UK: Sage.

Marsh, P. \& Triseliotis, J. (1996). Ready to practise? Social workers and probation officers: Their training and first year in social work. Aldershot, UK: Avebury.

Mills, M.A. (2008). What('s) theory? Journal of Folklore Research, 45(1), 19-28.

Mullaly, B. (1993). Structural social work: Ideology, theory, and practice. Toronto: McClelland \& Stewart.

Narey, M. (2014). Making the education of social workers consistently effective: Report of Sir Martin Narey's independent review of the education of children's social workers. London, UK: Department for Education.

Nevo, I. \& Slonim-Nevo, V. (2011). The myth of evidence-based practice: Towards evidenceinformed practice. British Journal of Social Work, 41(6), 1176-1197. doi:10.1093/bjsw/bcq149

O'Brien, M. (2004). What is social about social work? Social Work and Social Sciences Review, 11(2), 5-19.

Oko, J. (2011). Understanding and using theory in social work (2nd ed.). Exeter, UK: Learning Matters. 
Paley, J. (1987). Social work and the sociology of knowledge. British Journal of Social Work, $17(2), 169-186$.

Palmer, M. (2011). Disability and poverty: A conceptual review. Journal of Disability Policy Studies, 21(4), 210-218. doi:10.1177/1044207310389333

Payne, M. (2014). Modern social work theory (4th ed.). Basingstoke, UK: Palgrave Macmillan.

Peile, C. (1994). Theory, practice, research: Casual acquaintances or a seamless whole? Australian Social Work, 47(2), 17-23. doi:10.1080/03124079408411132

Penna, S. (2004). On the perils of applying theory to practice. Critical Social Work, 5(1). Retrieved from: http://www1.uwindsor.ca/criticalsocialwork/on-the-perils-of-applyingtheory-to-practice

Pilalis, J. (1986). "The integration of theory and practice": A re-examination of a paradoxical expectation. British Journal of Social Work, 16(1), 79-96.

Poulter, J. (2005). Integrating theory and practice: A new heuristic paradigm for social work practice. Australian Social Work, 58(2), 199-212. doi:10.1111/j.1447-0748.2005.00204.x

Pozzuto, R. (2007). Understanding theory, practicing social work. In S. L. Witkin \& D.

Saleebey (Eds.), Social work dialogues: Transforming the canon in inquiry, practice, and education (pp. 64-93). Alexandria, Council on Social Work Education.

Rojek, C., Peacock, G., \&Collins, S. (1988). Social work and received ideas. London, UK: Routledge.

Rubin, A. (2015). Efforts to bridge the gap between research and practice in social work: Precedents and prospects: Keynote address at the Bridging the Gap Symposium. Research on Social Work Practice, 25(4), 408-414. doi:10.1177/1049731514535852

Secker, J. (1993). From theory to practice in social work: The development of social work students' practice. Aldershot, UK: Avebury.

Sharland, E. (2012). All together now? Building disciplinary and inter-disciplinary research capacity in social work and social care. British Journal of Social Work, 42(2), 208-226. doi:10.1093/bjsw/bcr061

Sharland, E. (2013). Where are we now? Strengths and limitations of UK social work and social care research. Social Work and Social Sciences Review, 16(1), 7-19. doi:10.1921/300316206

Shaw, I. \& Norton, M. (2007). The kinds and quality of social work research in UK universities. London, UK: Social Care Institute for Excellence (SCIE). 
Sheldon, B. (1978). Theory and practice in social work: A re-examination of a tenuous relationship. British Journal of Social Work, 8(1), 1-22.

Sheldon, B. \& Macdonald, G. (2009). A textbook of social work. London, UK: Routledge.

Sheppard, M. (1998). Practice validity, reflexivity and knowledge for social work. British Journal of Social Work, 28(5), 763-791. doi:10.1093/oxfordjournals.bjsw.a011390

Sibeon, R. (1991a). The construction of a contemporary sociology of social work. In M. Davies (Ed.), The sociology of social work (pp. 17-67). London, UK: Routledge.

Sibeon, R. (1991b). Towards a new sociology of social work. Aldershot, UK: Avebury.

Singh, G. \& Cowden, S. (2009). The social worker as intellectual. European Journal of Social Work, 12(4), 479-493. doi:10.1080/13691450902840689

Smeeton, J. (2015). From Aristotle to Arendt: A phenomenological exploration of forms of knowledge and practice in the context of child protection social work in the UK. Qualitative Social Work. Advance online publication. doi:10.1177/1473325015603479

Smid, G. \& van Krieken, R. (1984). Notes on theory and practice in social work: A comparative view. British Journal of Social Work, 14(1), 11-22.

Smith, D. (1987). The limits of positivism in social work research. British Journal of Social Work, 17(4), 401-416.

Stanley, L. \& Wise, S. (2000). But the empress has no clothes! Some awkward questions about the "missing revolution" in feminist theory. Feminist Theory, 1(3), 261-288. doi:10.1177/146470010000100301

Statham, D. (1977). Radicals in social work. London, UK: Routledge \& Kegan Paul. Sung-Chan, P. \& Yuen-Tsang, A. (2008). Bridging the theory-practice gap in social work education: A reflection on an action research in China. Social Work Education, 27(1), 5169. doi:10.1080/02615470601141383

Taylor, C. \& White, S. (2000). Practising reflexivity in health and welfare: Making knowledge. Buckingham, UK: Open University Press.

Teater, B. (2014). An introduction to applying social work theories and methods (2nd ed.). Maidenhead, UK: Open University Press.

Thompson, N. (1992). Anti-discriminatory practice. Basingstoke, UK: Macmillan.

Thompson, N. (2010). Theorizing social work practice. Basingstoke, UK: Palgrave Macmillan.

Thyer, B.A. (2001). What is the role of theory in research on social work practice? Journal of Social Work Education, 37(1), 9-25. doi: 10.1080/10437797.2001.10779034 
Thyer, B.A. (2008). The quest for evidence-based practice?: We are all positivists! Research on Social Work Practice, 18(4), 339-345. doi:10.1177/1049731507313998

Timms, N. (1968). The language of social casework. London, UK: Routledge \& Kegan Paul.

Timms, N. \& Timms, R. (1977). Perspectives in social work. London, UK: Routledge \& Kegan Paul.

Trevithick, P. (2012). Social work skills and knowledge: A practice handbook (3rd ed.). Maidenhead, UK: Open University Press.

Turbett, C. (2014). Doing radical social work. Basingstoke, UK: Palgrave Macmillan.

Turner, F. J. (1974). Some considerations on the place of theory in current social work practice. In F. J. Turner (Ed.), Social work treatment: Interlocking theoretical approaches (pp. 3-16). New York: The Free Press.

Wachholz, S. \& Mullaly, B. (2001). The politics of the textbook: A content analysis of the coverage and treatment of feminist, radical and anti-racist social work scholarship in American introductory social work textbooks published between 1988 and 1997. Journal of Progressive Human Services, 11(2), 51-76. doi:10.1300/J059v11n02

Webb, S. (2001). Some considerations on the validity of evidence-based practice in social work. British Journal of Social Work, 31(1), 57-79. doi:10.1093/bjsw/31.1.57

Weick, A. (2000). Hidden voices. Social Work, 45(5), 395-402.

Witkin, S. (2011). Why do we think practice research is a good idea? Comments and musing inspired by the Salisbury Statement. Social Work and Society, 9(1), 10-19. Retrieved from: http://socwork.net/sws/article/view/3/13.

Witkin, S. (2016). Issues in researching professional practice: Deriving knowledge from professional practice. In J. Fook, V. Collington, F. Ross, G. Ruch, \& L. West (Eds.), Researching critical reflection: Multidisciplinary perspectives (pp. 109-118). London, UK: Routledge.

Witkin, S. \& Gottschalk, S. (1988). Alternative criteria for theory evaluation. Social Service Review, 62(2), 211-224.

Young, A., Carr, G., Hunt, R., McCracken, W., Skipp, A., \& Tattersall, H. (2006). Informed choice and deaf children: Underpinning concepts and enduring challenges. Journal of Deaf Studies and Deaf Education, 11(3), 322-336. doi:10.1093/deafed/enj041 


\section{Appendices:}

Table 1. Studies included or excluded from this review (with reasons for exclusions).

\begin{tabular}{|c|c|c|}
\hline Author(s) & $\begin{array}{l}\text { Date of article (unless } \\
\text { otherwise stated as book } \\
\text { etc.) }\end{array}$ & $\begin{array}{l}\text { Included in (I) or excluded } \\
\text { from (E) final } 93\end{array}$ \\
\hline Aldridge & 1996 & $\begin{array}{l}\text { E focused on neo-liberal } \\
\text { management }\end{array}$ \\
\hline Applegate & 2000 & E focused on postmodernism \\
\hline Arnd-Caddigan, Pozzuto & 2006 & $\begin{array}{l}\text { E used Arnd-Caddigan \& } \\
\text { Pozzuto } 2008\end{array}$ \\
\hline Arnd-Caddigan, Pozzuto & 2008 & I \\
\hline Askeland, Payne & 2001 & $\begin{array}{l}\text { E focused on knowledge and } \\
\text { validity }\end{array}$ \\
\hline Avby et al. & 2015 & I \\
\hline Aymer, Okitikpi & 2000 & $\begin{array}{l}\text { E focused on a teaching } \\
\text { module }\end{array}$ \\
\hline Ayre, Barrett & 2003 & I \\
\hline Bailey & 1982 chapter & E overview chapter \\
\hline Bailey \& Brake & 1975 & $\mathrm{I}$ \\
\hline Barbour & 1984 & I \\
\hline Barratt & 2003 & $\begin{array}{l}\text { E evidence-based practice } \\
\text { and child welfare }\end{array}$ \\
\hline Beckett & 2006 book & I \\
\hline Beresford & 2000 & $\begin{array}{l}\text { E used other representative } \\
\text { articles on power, service } \\
\text { users and theory }\end{array}$ \\
\hline Blom, Moren & 2010 & E focused on one theory \\
\hline Borden & 2010 chapter & I \\
\hline Brake \& Bailey & 1980 & I \\
\hline Brekke & 2012 & $\begin{array}{l}\text { E used other representative } \\
\text { pieces on science and social } \\
\text { work }\end{array}$ \\
\hline Briar-Lawson & 2012 & $\begin{array}{l}\text { E focused on critical realism, } \\
\text { used Houston } 2001\end{array}$ \\
\hline Brown & 1995 & $\begin{array}{l}\text { E evidence-based practice } \\
\text { debate, covered elsewhere }\end{array}$ \\
\hline Busch-Armendariz et al. & 2014 & E specific practice focus \\
\hline Carew & 1979 & $\mathrm{I}$ \\
\hline Carey & 2008 & $\begin{array}{l}\text { E focused on care } \\
\text { management }\end{array}$ \\
\hline Carey, Foster & $2011 \mathrm{a}$ & $\begin{array}{l}\text { E focused on radical social } \\
\text { work }\end{array}$ \\
\hline Carey, Foster & $2011 b$ & $\begin{array}{l}\text { E focused on discourse and } \\
\text { ideology }\end{array}$ \\
\hline Chambon & 1999 chapter & E focused on Foucault \\
\hline
\end{tabular}




\begin{tabular}{|c|c|c|}
\hline Chambon et al. & 2015 & $\begin{array}{l}\text { E focused on history of } \\
\text { social reform }\end{array}$ \\
\hline Chambon, Irving & 1994 book & $\begin{array}{l}\text { E focused on postmodern } \\
\text { theory }\end{array}$ \\
\hline Chan, Chan & 2004 & $\mathrm{I}$ \\
\hline Clark, Asquith & 1985 book & E focused on philosophy \\
\hline Coady & 2008 chapter & $\mathrm{I}$ \\
\hline Coady, Lehmann & 2008 book & $\begin{array}{l}\text { E used Coady } 2008 \text { as } \\
\text { representative }\end{array}$ \\
\hline Cohen & 1975 chapter & I \\
\hline Corby & 1982 & $\begin{array}{l}\text { E used other representative } \\
\text { studies }\end{array}$ \\
\hline Coulshed, Orme & 2012 book & I \\
\hline Cox & 2013 chapter & E overview chapter \\
\hline Cox & 1982 & $\begin{array}{l}\text { E focused on student } \\
\text { expectations }\end{array}$ \\
\hline Cox, Hardwick & 2002 & E focused on teaching \\
\hline Cree & 2010 book & E overview textbook \\
\hline Cree & 1995 book & $\begin{array}{l}\text { E focus on discourse on role } \\
\text { of social work profession }\end{array}$ \\
\hline Cunningham, Cunningham & 2014 book & E sociology textbook \\
\hline Curnock, Hardiker & 1979 book & $\mathrm{I}$ \\
\hline D’Cruz et al. & $2007 \mathrm{a}$ & E focused on reflexivity \\
\hline D'Cruz et al. & $2007 b$ & E as above \\
\hline Davies & 1991 book & E overview sociology text \\
\hline Dibicz, Pyles & 2011 & $\begin{array}{l}\text { E focused on dialectic } \\
\text { method }\end{array}$ \\
\hline Dominelli & 2002 book & $\begin{array}{l}\text { E focused on feminist social } \\
\text { work }\end{array}$ \\
\hline Dunk-West, Verity & 2013 book & E sociology textbook \\
\hline England & 1986 book & I \\
\hline Epstein & 1995 & $\begin{array}{l}\text { E evidence-based practice } \\
\text { debate }\end{array}$ \\
\hline Evans & 1976 & I \\
\hline Evans, Hardy & 2010 book & $\begin{array}{l}\text { E used other representative } \\
\text { texts }\end{array}$ \\
\hline Fargion & 2007 & E focused on language use \\
\hline Ferguson & 2009 & I \\
\hline Ferguson & 2008 book & E used Ferguson 2009 \\
\hline Ferguson \& Woodward & 2009 & I \\
\hline Figueira-McDonough et al. & 2001 & $\begin{array}{l}\text { E focused on feminist } \\
\text { teaching }\end{array}$ \\
\hline Fisher, Somerton & 2000 & $\begin{array}{l}\text { E focused on teaching of } \\
\text { reflection }\end{array}$ \\
\hline Floersch & 2000 & E used Floersch 2004 \\
\hline Floersch & 2004 & I \\
\hline Fong & 2012 & $\begin{array}{l}\text { E used other representative } \\
\text { pieces on science and social } \\
\text { work }\end{array}$ \\
\hline
\end{tabular}




\begin{tabular}{|c|c|c|}
\hline Fook & 2011 & $\begin{array}{l}\text { E looked at uncertainty, used } \\
\text { her empirical studies instead }\end{array}$ \\
\hline Fook & 2002 & I \\
\hline Fook & 2012 book & $\mathrm{I}$ \\
\hline Fook et al. & 2000 book & I \\
\hline Fook et al. & 1996 & $\begin{array}{l}\text { E used Fook et al. 1997, } \\
2000\end{array}$ \\
\hline Fook et al. & 1997 & $\mathrm{I}$ \\
\hline Forte & 2014a book & E overview textbook \\
\hline Forte & 2014b book & E skills textbook \\
\hline Gambrill & 1994 & E used Gambrill 2012 \\
\hline Gambrill & 1995 & E reply to critique piece \\
\hline Gambrill & 2012 & $\mathrm{I}$ \\
\hline Garrett & 2015 & E focused on Wacquant \\
\hline Garrett & 2013 book & I \\
\hline Garrity & 2010 & $\begin{array}{l}\text { E focused on discourse } \\
\text { theory }\end{array}$ \\
\hline Gilbert et al. & 2009 & $\begin{array}{l}\text { E focused on evidence based } \\
\text { practice }\end{array}$ \\
\hline Gilbert, Powell & 2010 & E focused on Foucault \\
\hline Gomory & $2001 \mathrm{a}$ & I \\
\hline Gomory & $2001 b$ & $\begin{array}{l}\text { E focused on response to } \\
\text { Thyer }\end{array}$ \\
\hline Graham & 1999 & $\mathrm{I}$ \\
\hline Graham & 2007 book & E used Graham 1999 \\
\hline Gray & 1995 & E focused on ethics \\
\hline Gray et al. & 2009 book & $\begin{array}{l}\text { E used other responses to } \\
\text { evidence-based practice }\end{array}$ \\
\hline Gray, Schubert & 2013 & $\begin{array}{l}\text { E focused on knowledge } \\
\text { transfer }\end{array}$ \\
\hline Gray, Webb & 2013 chapter & E overview intro \\
\hline Gray, Webb & 2013 book & E overview textbook \\
\hline Gray, Webb & 2008 & $\begin{array}{l}\text { E overview of England } 1986 \\
\text { and response }\end{array}$ \\
\hline Gray, Webb & 2009 & $\begin{array}{l}\text { E focused on critical social } \\
\text { work }\end{array}$ \\
\hline Green & 2006 & I \\
\hline Greene & 2009 chapter & I \\
\hline Grimwood & 2016 book & I \\
\hline Hardiker, Barker & 1981 book & E overview textbook \\
\hline Hardy, Jobling & 2015 & $\begin{array}{l}\text { E focused on } \\
\text { governmentality and } \\
\text { knowledge flow }\end{array}$ \\
\hline Harris et al. & 2014 & $\begin{array}{l}\text { E discussion of international } \\
\text { knowledge exchange }\end{array}$ \\
\hline Harston & 2004 & E focused on Buddhism \\
\hline Healy & 2008 & E critical commentary \\
\hline Healy & 2014 book & $\mathrm{I}$ \\
\hline Heineman & 1981 & $\mathrm{I}$ \\
\hline
\end{tabular}




\begin{tabular}{|c|c|c|}
\hline Heinsch et al. & 2016 & $\mathrm{I}$ \\
\hline Hick et al. & 2005 & I \\
\hline Houston & $2014 \mathrm{a}$ & I \\
\hline Houston & $2014 b$ & E looks at identity \\
\hline Houston & 2001 & I \\
\hline Houston & 2004 & $\begin{array}{l}\text { E overview of } \\
\text { Garrett/Ferguson debate }\end{array}$ \\
\hline Houston & 2002 & $\begin{array}{l}\text { E focused on systems theory } \\
\text { and child welfare }\end{array}$ \\
\hline Houston & 2005 & $\begin{array}{l}\text { E used other pieces by } \\
\text { Houston } 20012014\end{array}$ \\
\hline Houston & 2012 & E used Houston 2001, 2014 \\
\hline Howe & 1996 chapter & I \\
\hline Howe & 1987 book & I \\
\hline Howe & 1994 & E focused on postmodernity \\
\hline Howe & 2009 book & E used Howe 1987 \\
\hline Jeyasingham & 2008 & $\begin{array}{l}\text { E focused on sexuality } \\
\text { theory }\end{array}$ \\
\hline Johnsson, Svensson & 2005 & E overview text \\
\hline Jones & 1996 chapter & I \\
\hline Jordan & 1978 & $\begin{array}{l}\text { E used other pieces on the } \\
\text { evidence-based practice and } \\
\text { responses debate }\end{array}$ \\
\hline Karger, Hernandez & 2004 & $\begin{array}{l}\text { E used other texts on the } \\
\text { intellectual and social work } \\
\text { e.g. Singh \& Cowden } 2009\end{array}$ \\
\hline Kirk, Reid & 2002 book & $\begin{array}{l}\text { E focused on science and } \\
\text { evidence-based practice, } \\
\text { used other representative } \\
\text { articles e.g. Thyer }\end{array}$ \\
\hline Kondrat & 2002 & E used 1995 piece \\
\hline Kondrat & 1992 & E used Kondrat 1995 \\
\hline Kondrat & 1999 & E focused on self-awareness \\
\hline Kondrat & 1995 & I \\
\hline Kreisberg, Marsh & 2015 & I \\
\hline Kunzel & 1993 book & $\begin{array}{l}\text { E focused on history of work } \\
\text { with unmarried mothers }\end{array}$ \\
\hline Langan \& Lee & 1989 & I \\
\hline Lavalette & 2011 & I \\
\hline Lee & 1982 chapter & $\begin{array}{l}\text { E overview of } \\
\text { theory/practice }\end{array}$ \\
\hline Leonard & 1975 & I \\
\hline Leonard & 1997 book & $\begin{array}{l}\text { E focused on postmodern } \\
\text { politics }\end{array}$ \\
\hline Lishman & 2007 book & E overview textbook \\
\hline Llewellyn et al. & 2008 book & E sociology textbook \\
\hline Loewenberg & 1984 & $\begin{array}{l}\text { E used other representative } \\
\text { studies }\end{array}$ \\
\hline
\end{tabular}




\begin{tabular}{|c|c|c|}
\hline Longhofer, Floersch & 2012 & $\begin{array}{l}\text { E used other representative } \\
\text { pieces on science and social } \\
\text { work }\end{array}$ \\
\hline Lorenz & 2012 & E focused on hermeneutics \\
\hline Lorenz & 1994 book & $\begin{array}{l}\text { E focused on European } \\
\text { social work politics }\end{array}$ \\
\hline Mackey et al. & 1987 & I \\
\hline MacKinnon & 2009 & $\begin{array}{l}\text { E used other texts on the } \\
\text { intellectual and social work } \\
\text { e.g. Singh \& Cowden } 2009\end{array}$ \\
\hline Maclean, Harrison & 2015 book & E overview textbook \\
\hline Mantysaari, Weatherley & 2010 chapter & I \\
\hline Margolin & 1997 book & $\begin{array}{l}\text { E focused on history of } \\
\text { surveillance and power }\end{array}$ \\
\hline Marsh & 2012 & $\begin{array}{l}\text { E used other representative } \\
\text { pieces on science and social } \\
\text { work }\end{array}$ \\
\hline Marsh et al. & 2005 & $\begin{array}{l}\text { E focused on knowledge } \\
\text { types }\end{array}$ \\
\hline Marsh, Triseliotis & 1996 book & $\mathrm{I}$ \\
\hline Mayer, Timms & 1970 book & $\begin{array}{l}\text { E focused on class and } \\
\text { poverty }\end{array}$ \\
\hline McBeath, Webb & 2005 & $\begin{array}{l}\text { E focused on critical social } \\
\text { work }\end{array}$ \\
\hline McBeath, Webb & 1991 & E as above \\
\hline McDermott & 1975 book & $\begin{array}{l}\text { E focused on philosophy of } \\
\text { self-determination }\end{array}$ \\
\hline McLaughlin & 2008 book & $\begin{array}{l}\text { E focused on radical social } \\
\text { work and mental health }\end{array}$ \\
\hline Mikailakis, Schirmer & 2014 & E focused on systems theory \\
\hline Moffatt & 2001 book & $\begin{array}{l}\text { E history of ideas specific to } \\
\text { Canada }\end{array}$ \\
\hline Mullaly & 1993 & $\mathrm{I}$ \\
\hline Munro & 2002 & E overview text \\
\hline Narey & 2014 report & $\mathrm{I}$ \\
\hline Nash et al. & 2005 book & E overview textbook \\
\hline Nevo, Slonim-Nevo & 2011 & $\mathrm{I}$ \\
\hline Nissen & 2013 & E focused on sociology \\
\hline Noble & 2004 & E focused on postmodernism \\
\hline O’Brien & 2004 & I \\
\hline O’Brien, Penna & 1998 chapter & $\begin{array}{l}\text { E used other pieces by both } \\
\text { authors }\end{array}$ \\
\hline O’Brien, Penna & 1998 book & E overview textbook \\
\hline Oak & 2009 book & E overview text \\
\hline Okitikpi, Aymer & 2010 book & $\begin{array}{l}\text { E focused on anti- } \\
\text { discriminatory perspectives }\end{array}$ \\
\hline Oko & 2011 book & I \\
\hline Olsson, Ljunghill & 1997 & $\begin{array}{l}\text { E used other representative } \\
\text { studies }\end{array}$ \\
\hline
\end{tabular}




\begin{tabular}{|c|c|c|}
\hline Orme, Briar-Lawson & 2010 chapter & E focus on policy \\
\hline Osmond, O'Connor & 2006 & $\begin{array}{l}\text { E used other representative } \\
\text { studies }\end{array}$ \\
\hline Osmond, O'Connor & 2004 & $\begin{array}{l}\text { E used other pieces on tacit } \\
\text { knowledge/practice wisdom }\end{array}$ \\
\hline Paley & 1984 & $\begin{array}{l}\text { E used other representative } \\
\text { pieces }\end{array}$ \\
\hline Paley & 1987 & I \\
\hline Parton & 2003 & $\begin{array}{l}\text { E focused on specific ethical } \\
\text { models }\end{array}$ \\
\hline Parton & 2000 & $\begin{array}{l}\text { E used other pieces on } \\
\text { technical-rational 'vs' } \\
\text { interpretive theory }\end{array}$ \\
\hline Pawson et al. & 2003 report & $\begin{array}{l}\text { E largely focused on } \\
\text { knowledge review in social } \\
\text { care }\end{array}$ \\
\hline Payne & 2010 & $\begin{array}{l}\text { E used } 2014 \text { text as } \\
\text { representative }\end{array}$ \\
\hline Payne & 2009 & E used Payne 2014 \\
\hline Payne & 2002 & E focused on systems theory \\
\hline Payne & 2014 book & I \\
\hline Pease, Fook & 1999 book & $\begin{array}{l}\text { E focused on postmodern } \\
\text { theory }\end{array}$ \\
\hline Peile & 1988 & $\mathrm{E}$ as above \\
\hline Peile & 1994 & I \\
\hline Peile, McCouat & 1997 & E looked at Peile 1994 \\
\hline Penna & 2004 & I \\
\hline Philp & 1979 & E focused on Foucault \\
\hline Pilalis & 1986 & I \\
\hline Platt & 2007 report & $\begin{array}{l}\text { E social care review, used } \\
\text { Narey } 2014\end{array}$ \\
\hline Poulter & 2005 & $\mathrm{I}$ \\
\hline Powell & 2001 book & $\begin{array}{l}\text { E focused on critical and } \\
\text { radical theories }\end{array}$ \\
\hline Powell, Carey & 2007 & $\begin{array}{l}\text { E focused on Butler, } \\
\text { Fouccault }\end{array}$ \\
\hline Pozzuto & 2007 chapter & I \\
\hline Price, Simpson & 2007 book & E as above \\
\hline Reid & 1997 & $\begin{array}{l}\text { E focused on } \\
\text { outcomes/evidence }\end{array}$ \\
\hline Reid & 2003 & $\begin{array}{l}\text { E used other representative } \\
\text { articles }\end{array}$ \\
\hline Reid & 1994 & $\begin{array}{l}\text { E used other representative } \\
\text { articles }\end{array}$ \\
\hline Reid & $1995 \mathrm{a}$ & E as above \\
\hline Reid & $1995 \mathrm{~b}$ & E as above \\
\hline Riemann & 2005 & $\begin{array}{l}\text { E focused on ethnographic } \\
\text { methodology }\end{array}$ \\
\hline
\end{tabular}




\begin{tabular}{|c|c|c|}
\hline Riley & 1996 & $\begin{array}{l}\text { E focused on postmodern } \\
\text { theory }\end{array}$ \\
\hline Rojek & 1986 & E used Rojek et al. 1988 \\
\hline Rojek et al. & 1988 book & I \\
\hline Rosen & 1994 & $\begin{array}{l}\text { E used other representative } \\
\text { studies }\end{array}$ \\
\hline Rubin & 2015 & $\mathrm{I}$ \\
\hline Saleebey & 2013 book & $\begin{array}{l}\text { E focused on strengths } \\
\text { perspective }\end{array}$ \\
\hline Schiele & 1996 & E focused on Afrocentricity \\
\hline Schirmer, Mikailakis & 2013 & E focused on Luhmann \\
\hline Scott & 1989 & $\begin{array}{l}\text { E focused on mode of } \\
\text { (research) inquiry }\end{array}$ \\
\hline Secker & 1993 book & $\mathrm{I}$ \\
\hline Sharland & 2009 report & E used Sharland 2012, 2013 \\
\hline Sharland & 2012 & $\mathrm{I}$ \\
\hline Sharland & 2013 & I \\
\hline Shaw & 2013 chapter & $\begin{array}{l}\text { E used Shaw \& Norton } 2007 \\
\text { and other representative } \\
\text { pieces }\end{array}$ \\
\hline Shaw & 2012 book & E used Shaw \& Norton 2007 \\
\hline Shaw, Norton & 2007 report & I \\
\hline Shaw, Norton & 2008 & $\begin{array}{l}\text { E, used } 2007 \text { as } \\
\text { representative }\end{array}$ \\
\hline Sheldon & 1978 & $\mathrm{I}$ \\
\hline Sheldon & 2001 & E used Sheldon 1978 \\
\hline Sheldon, Macdonald & 2009 book & I \\
\hline Sheppard & 2006 & $\begin{array}{l}\text { E used another } \\
\text { representative article }\end{array}$ \\
\hline Sheppard & 1995 & $\begin{array}{l}\text { E used Sheppard } 1998 \text { as } \\
\text { representative }\end{array}$ \\
\hline Sheppard & 1998 & I \\
\hline Sheppard et al. & 2000 & $\begin{array}{l}\text { E used other studies on } \\
\text { practice theory and Sheppard } \\
1998\end{array}$ \\
\hline Sheppard, Charles & 2014 & $\begin{array}{l}\text { E used another } \\
\text { representative article }\end{array}$ \\
\hline Sheppard, Ryan & 2003 & E used Sheppard 1998 \\
\hline Sibeon & 1991 a chapter & I \\
\hline Sibeon & 1991b book & $\mathrm{I}$ \\
\hline Singh, Cowden & 2009 & $\mathrm{I}$ \\
\hline Smeeton & 2015 & $\mathrm{I}$ \\
\hline Smid, van Krieken & 1984 & I \\
\hline Smith & 2001 & E focused on postmodernity \\
\hline Smith & 1987 & $\mathrm{I}$ \\
\hline Smith & 2008 book & E focused on power theories \\
\hline Smith, White & 1997 & $\begin{array}{l}\text { E overview of postmodernity } \\
\text { debate and reply }\end{array}$ \\
\hline
\end{tabular}




\begin{tabular}{|c|c|c|}
\hline Soydan & 2012 & $\begin{array}{l}\text { E used other representative } \\
\text { pieces on science and social } \\
\text { work }\end{array}$ \\
\hline Soydan & 1999 book & $\begin{array}{l}\text { E historical account of } \\
\text { national ideas }\end{array}$ \\
\hline Soydan, Palinkas & 2014 book & $\begin{array}{l}\text { E used other pieces on } \\
\text { evidence based practice }\end{array}$ \\
\hline Statham & 1977 & I \\
\hline Stevenson & 2013 book & E autobiographical memoir \\
\hline Sung-Chan, Yuen-Tsang & 2008 & I \\
\hline Swigonski & 1996 & E focused on Afrocentricity \\
\hline Taylor & 2012 & $\begin{array}{l}\text { E focused on decision- } \\
\text { making models }\end{array}$ \\
\hline Taylor & 2004 & E child development theory \\
\hline Taylor, White & 2000 book & I \\
\hline Teater & 2014 book & I \\
\hline Thompson & 2010 book & I \\
\hline Thompson & 2012 book & $\begin{array}{l}\text { I (have referred to original } \\
1992 \text { version) }\end{array}$ \\
\hline Thyer & 2008 & I \\
\hline Thyer & $2001 \mathrm{a}$ & I \\
\hline Thyer & $2001 \mathrm{~b}$ & E used Thyer 2008 \\
\hline Timms & 1968 book & I \\
\hline Timms, Timms & 1977 book & I \\
\hline Trevithick & 2008 & E used Trevithick 2012 \\
\hline Trevithick & 2012 book & I \\
\hline Tsang & 1998 & E overview text \\
\hline Turbett & 2014 & I \\
\hline Turner & 1990 & E focused on health \\
\hline Turner & 1974 chapter & I \\
\hline Turney, Ruch & 2015 & $\begin{array}{l}\text { E focused on cognitive } \\
\text { interviewing }\end{array}$ \\
\hline Ungar & 2004 & E focused on postmodernism \\
\hline Van de Luitgaarden & 2009 & $\begin{array}{l}\text { E overview of evidence } \\
\text { based practice }\end{array}$ \\
\hline Wachholz, Mullaly & 2001 & I \\
\hline Wakefield, Kirk & 1996 & $\begin{array}{l}\text { E used other articles on } \\
\text { evidence based debate }\end{array}$ \\
\hline Walsh & 2010 book & E overview textbook \\
\hline Webb & 2001 & I \\
\hline Webb & 2010 & $\begin{array}{l}\text { E focused on } \\
\text { redistribution/recognition }\end{array}$ \\
\hline Webb & 2006 book & E used Webb 2001 \\
\hline Webber et al. & 2014 & E focused on universities \\
\hline Weick & 2000 & I \\
\hline Weick & 1991 & $\begin{array}{l}\text { E used other representative } \\
\text { pieces on science and social } \\
\text { work }\end{array}$ \\
\hline
\end{tabular}




\begin{tabular}{|l|l|l|}
\hline Weick & 1987 & $\begin{array}{l}\text { E response to evidence- } \\
\text { based models }\end{array}$ \\
\hline Weick, Saleebey & 1998 & E focused on postmodernism \\
\hline White & 1997 & $\begin{array}{l}\text { E debate with Sheppard on } \\
\text { reflexivity/retroduction }\end{array}$ \\
\hline White & 2006 book & E focused on feminist theory \\
\hline White, Stancombe & 2003 book & E used Taylor \& White 2000 \\
\hline Witkin & 2011 & I \\
\hline Witkin & 1996 & E used Witkin 2011, 2016 \\
\hline Witkin & 2016 chapter & I \\
\hline Witkin & 2012 book & $\begin{array}{l}\text { E focused on social } \\
\text { constructionism }\end{array}$ \\
\hline Witkin, Gottschalk & 1988 & I \\
\hline Zeira, Rosen & 2000 & $\begin{array}{l}\text { E used other representative } \\
\text { pieces on practice wisdom }\end{array}$ \\
\hline
\end{tabular}


Table 2. Analysis of whether tropes 1-5 are addressed by the 93 studies in this review.

\begin{tabular}{|c|c|c|c|c|c|c|}
\hline Author(s) & Date & $\begin{array}{l}1 . \\
\text { Definitional } \\
\text { questions } \\
\text { and } \\
\text { ambiguity: } \\
(87 / 93) \\
93 \%\end{array}$ & $\begin{array}{l}2 . \\
\text { Empirical } \\
\text { study of } \\
\text { theory } \\
\text { and social } \\
\text { work: } \\
(16 / 93) \\
18 \%\end{array}$ & $\begin{array}{l}3 . \\
\text { Hostility } \\
\text { towards } \\
\text { theory: } \\
(37 / 93) \\
38 \%\end{array}$ & $\begin{array}{l}4 . \\
\text { Theory/ } \\
\text { practice } \\
\text { divide: } \\
(59 / 93) \\
65 \%\end{array}$ & $\begin{array}{l}5 . \\
\text { Theory's } \\
\text { utility } \\
\text { and/or } \\
\text { function: } \\
(71 / 93) \\
76 \%\end{array}$ \\
\hline $\begin{array}{l}\text { Arnd- } \\
\text { Caddigan, } \\
\text { Pozzuto }\end{array}$ & 2008 & $\mathrm{x}$ & $\mathrm{x}$ & & $\mathrm{x}$ & $\mathrm{x}$ \\
\hline Avby et al. & 2015 & & $\mathrm{x}$ & $\mathrm{x}$ & $\mathrm{x}$ & $\mathrm{x}$ \\
\hline Ayre, Barrett & 2003 & $\mathrm{x}$ & & & $\mathrm{x}$ & \\
\hline Bailey, Brake & 1975 & $\mathrm{x}$ & & $\mathrm{x}$ & $\mathrm{x}$ & $\mathrm{x}$ \\
\hline Barbour & 1984 & $\mathrm{x}$ & $\mathrm{x}$ & $\mathrm{x}$ & $\mathrm{x}$ & $\mathrm{x}$ \\
\hline Beckett & 2006 & $\mathrm{x}$ & & $\mathrm{x}$ & & $\mathrm{x}$ \\
\hline Borden & 2010 & $\mathrm{x}$ & & $\mathrm{x}$ & $\mathrm{x}$ & \\
\hline Brake, Bailey & 1980 & $\mathrm{x}$ & & $\mathrm{x}$ & $\mathrm{x}$ & $\mathrm{x}$ \\
\hline Carew & 1979 & & $\mathrm{x}$ & & $\mathrm{x}$ & $\mathrm{x}$ \\
\hline Chan, Chan & 2004 & $\mathrm{x}$ & $\mathrm{x}$ & & $\mathrm{x}$ & \\
\hline Coady & 2008 & $\mathrm{x}$ & & & & \\
\hline Cohen & 1975 & $\mathrm{x}$ & & $\mathrm{x}$ & $\mathrm{x}$ & $\mathrm{x}$ \\
\hline $\begin{array}{l}\text { Coulshed, } \\
\text { Orme }\end{array}$ & 2012 & $\mathrm{x}$ & & & $\mathrm{x}$ & \\
\hline $\begin{array}{l}\text { Curnock, } \\
\text { Hardiker }\end{array}$ & 1979 & $\mathrm{x}$ & $\mathrm{x}$ & & $\mathrm{x}$ & $\mathrm{x}$ \\
\hline England & 1986 & $\mathrm{x}$ & & $\mathrm{x}$ & $\mathrm{x}$ & \\
\hline Evans & 1976 & $\mathrm{x}$ & & & $\mathrm{x}$ & \\
\hline Ferguson & 2009 & $\mathrm{x}$ & & & & $\mathrm{x}$ \\
\hline $\begin{array}{l}\text { Fergsuon, } \\
\text { Woodward }\end{array}$ & 2009 & $\mathrm{x}$ & & $\mathrm{x}$ & $\mathrm{x}$ & $\mathrm{x}$ \\
\hline Floersch & 2004 & $\mathrm{x}$ & & & $\mathrm{x}$ & \\
\hline Fook & 2002 & $\mathrm{x}$ & & & $\mathrm{x}$ & \\
\hline Fook & 2012 & $\mathrm{x}$ & & & $\mathrm{x}$ & $\mathrm{x}$ \\
\hline Fook et al. & 2000 & $\mathrm{x}$ & $\mathrm{x}$ & & $\mathrm{x}$ & \\
\hline Fook et al. & 1997 & $\mathrm{x}$ & $\mathrm{x}$ & & $\mathrm{x}$ & \\
\hline Gambrill & 2012 & $\mathrm{x}$ & & & & $\mathrm{x}$ \\
\hline Garrett & 2013 & $\mathrm{x}$ & & $\mathrm{x}$ & $\mathrm{x}$ & $\mathrm{x}$ \\
\hline Gomory & 2001 & $\mathrm{x}$ & & $\mathrm{x}$ & & $\mathrm{x}$ \\
\hline Graham & 1999 & $\mathrm{x}$ & & & & \\
\hline Green & 2006 & $\mathrm{x}$ & & $\mathrm{x}$ & $\mathrm{x}$ & $\mathrm{x}$ \\
\hline Greene & 2009 & $\mathrm{x}$ & & & & $\mathrm{x}$ \\
\hline Grimwood & 2016 & $\mathrm{x}$ & & & & $\mathrm{x}$ \\
\hline Healy & 2014 & $\mathrm{x}$ & & & $\mathrm{x}$ & \\
\hline Heineman & 1981 & $\mathrm{x}$ & & & & $\mathrm{x}$ \\
\hline Heinsch et al. & 2016 & $\mathrm{x}$ & & & & $\mathrm{x}$ \\
\hline Hick et al. & 2005 & $\mathrm{x}$ & & $\mathrm{x}$ & $\mathrm{x}$ & $\mathrm{x}$ \\
\hline
\end{tabular}




\begin{tabular}{|c|c|c|c|c|c|c|}
\hline Houston & 2014 & $\mathrm{x}$ & & & & $\mathrm{X}$ \\
\hline Houston & 2001 & $\mathrm{x}$ & & & & $\mathrm{X}$ \\
\hline Howe & 1996 & $\mathrm{x}$ & & & $\mathrm{x}$ & $\mathrm{x}$ \\
\hline Howe & 1987 & $\mathrm{x}$ & & $\mathrm{x}$ & $\mathrm{x}$ & \\
\hline Jones & 1996 & $\mathrm{x}$ & & $\mathrm{x}$ & $\mathrm{x}$ & $\mathrm{x}$ \\
\hline Kondrat & 1995 & $\mathrm{x}$ & & & $\mathrm{x}$ & $\mathrm{x}$ \\
\hline $\begin{array}{l}\text { Kreisberg, } \\
\text { Marsh }\end{array}$ & 2015 & & $\mathrm{x}$ & & & $\mathrm{x}$ \\
\hline Langan, Lee & 1989 & $\mathrm{x}$ & & $\mathrm{x}$ & $\mathrm{x}$ & $\mathrm{X}$ \\
\hline Lavalette & 2011 & $\mathrm{x}$ & & $\mathrm{x}$ & $\mathrm{x}$ & $\mathrm{X}$ \\
\hline Leonard & 1975 & $\mathrm{x}$ & & & & $\mathrm{x}$ \\
\hline Mackey et al. & 1987 & & $\mathrm{x}$ & & & $\mathrm{x}$ \\
\hline $\begin{array}{l}\text { Mantysaari, } \\
\text { Weatherley }\end{array}$ & 2010 & $\mathrm{x}$ & & & & $\mathrm{x}$ \\
\hline $\begin{array}{l}\text { Marsh, } \\
\text { Triseliotis }\end{array}$ & 1996 & & $\mathrm{x}$ & $\mathrm{x}$ & $\mathrm{x}$ & $\mathrm{x}$ \\
\hline Mullaly & 1993 & $\mathrm{x}$ & & $\mathrm{x}$ & $\mathrm{x}$ & $\mathrm{X}$ \\
\hline Narey & 2014 & & & $\mathrm{x}$ & $\mathrm{x}$ & \\
\hline $\begin{array}{l}\text { Nevo, } \\
\text { Slonim-Nevo }\end{array}$ & 2011 & $\mathrm{x}$ & & & $\mathrm{x}$ & $\mathrm{x}$ \\
\hline O'Brien & 2004 & $\mathrm{x}$ & & $\mathrm{x}$ & & \\
\hline Oko & 2011 & $\mathrm{x}$ & & $\mathrm{x}$ & $\mathrm{x}$ & $\mathrm{X}$ \\
\hline Paley & 1987 & $\mathrm{x}$ & & $\mathrm{x}$ & $\mathrm{x}$ & \\
\hline Payne & 2014 & $\mathrm{x}$ & & $\mathrm{x}$ & $\mathrm{x}$ & $\mathrm{X}$ \\
\hline Peile & 1994 & $\mathrm{x}$ & & $\mathrm{x}$ & $\mathrm{x}$ & $\mathrm{X}$ \\
\hline Penna & 2004 & $\mathrm{x}$ & & & $\mathrm{x}$ & $\mathrm{x}$ \\
\hline Pilalis & 1986 & $\mathrm{x}$ & & & $\mathrm{x}$ & $\mathrm{x}$ \\
\hline Poulter & 2005 & $\mathrm{x}$ & & & $\mathrm{x}$ & $\mathrm{x}$ \\
\hline Pozzuto & 2007 & $\mathrm{x}$ & & & & $\mathrm{x}$ \\
\hline Rojek et al. & 1988 & $\mathrm{x}$ & & & & $\mathrm{X}$ \\
\hline Rubin & 2015 & $\mathrm{x}$ & & $\mathrm{x}$ & & \\
\hline Secker & 1993 & $\mathrm{x}$ & $\mathrm{X}$ & $\mathrm{x}$ & $\mathrm{x}$ & $\mathrm{x}$ \\
\hline Sharland & 2012 & $\mathrm{x}$ & $\mathrm{x}$ & & & $\mathrm{x}$ \\
\hline Sharland & 2013 & $\mathrm{x}$ & $\mathrm{x}$ & & & $\mathrm{x}$ \\
\hline Shaw, Norton & 2007 & $\mathrm{x}$ & $\mathrm{x}$ & & & $\mathrm{x}$ \\
\hline Sheldon & 1978 & $\mathrm{x}$ & & & $\mathrm{x}$ & $\mathrm{x}$ \\
\hline $\begin{array}{l}\text { Sheldon, } \\
\text { Macdonald }\end{array}$ & 2009 & $\mathrm{x}$ & & & $\mathrm{x}$ & $\mathrm{x}$ \\
\hline Sheppard & 1998 & $\mathrm{x}$ & & & $\mathrm{x}$ & $\mathrm{X}$ \\
\hline Sibeon & $1991 \mathrm{a}$ & $\mathrm{x}$ & & $\mathrm{x}$ & $\mathrm{x}$ & $\mathrm{x}$ \\
\hline Sibeon & $1991 b$ & $\mathrm{x}$ & & $\mathrm{x}$ & $\mathrm{x}$ & $\mathrm{x}$ \\
\hline $\begin{array}{l}\text { Singh, } \\
\text { Cowden }\end{array}$ & 2009 & $\mathrm{x}$ & & $\mathrm{x}$ & $\mathrm{x}$ & $\mathrm{x}$ \\
\hline Smeeton & 2015 & $\mathrm{x}$ & & & $\mathrm{x}$ & $\mathrm{X}$ \\
\hline $\begin{array}{l}\text { Smid, van } \\
\text { Krieken }\end{array}$ & 1984 & $\mathrm{x}$ & & & $\mathrm{x}$ & \\
\hline Smith & 1987 & $\mathrm{X}$ & & & & $\mathrm{X}$ \\
\hline Statham & 1977 & $\mathrm{x}$ & & $\mathrm{x}$ & $\mathrm{x}$ & $\mathrm{x}$ \\
\hline
\end{tabular}




\begin{tabular}{|l|l|l|l|l|l|l|}
\hline $\begin{array}{l}\text { Sung-Chan, } \\
\text { Yuen-Tsang }\end{array}$ & 2008 & $\mathrm{x}$ & & $\mathrm{x}$ & \\
\hline Taylor, White & 2000 & $\mathrm{x}$ & & & & $\mathrm{x}$ \\
\hline Teater & 2014 & $\mathrm{x}$ & & & & $\mathrm{x}$ \\
\hline Thompson & 1992 & $\mathrm{x}$ & $\mathrm{x}$ & $\mathrm{x}$ & $\mathrm{x}$ \\
\hline Thompson & 2010 & $\mathrm{x}$ & $\mathrm{x}$ & $\mathrm{x}$ & $\mathrm{x}$ \\
\hline Thyer & 2001 & $\mathrm{x}$ & $\mathrm{x}$ & & $\mathrm{x}$ \\
\hline Thyer & 2008 & $\mathrm{x}$ & & $\mathrm{x}$ & $\mathrm{x}$ & $\mathrm{x}$ \\
\hline Timms & 1968 & $\mathrm{x}$ & & & & $\mathrm{x}$ \\
\hline $\begin{array}{l}\text { Timms } \\
\text { Timms }\end{array}$ & 1977 & $\mathrm{x}$ & & $\mathrm{x}$ & $\mathrm{x}$ & $\mathrm{x}$ \\
\hline Trevithick & 2012 & $\mathrm{x}$ & & $\mathrm{x}$ & $\mathrm{x}$ & $\mathrm{x}$ \\
\hline Turbett & 2014 & $\mathrm{x}$ & & & & $\mathrm{x}$ \\
\hline Turner & 1974 & $\mathrm{x}$ & $\mathrm{x}$ & & & $\mathrm{x}$ \\
\hline $\begin{array}{l}\text { Wachholz, } \\
\text { Mullaly }\end{array}$ & 2001 & $\mathrm{x}$ & & & $\mathrm{x}$ & $\mathrm{x}$ \\
\hline Webb & 2001 & $\mathrm{x}$ & & & $\mathrm{x}$ & \\
\hline Weick & 2000 & $\mathrm{x}$ & & & $\mathrm{x}$ \\
\hline Witkin & 2011 & $\mathrm{x}$ & & & $\mathrm{x}$ \\
\hline Witkin & 2016 & $\mathrm{x}$ & $\mathrm{x}$ & & & \\
\hline $\begin{array}{l}\text { Witkin, } \\
\text { Gottschalk }\end{array}$ & 1988 & & & & & \\
\hline
\end{tabular}

